\title{
Computing Cartel Overcharges: when theory meets practice
}

\author{
Renato Nunes de Lima Seixas ${ }^{1}$ \\ Claudio Ribeiro de Lucinda ${ }^{2}$
}

\begin{abstract}
Success in law enforcement of cartel cases hinges on solid investigation procedures and effective punishment. However, the existing legal framework provides guidance on computing fines based on sales revenue, even though it mentions such fines must be no lower than cartel gains. Using data from a real case in Brazil, this paper has two aims: (i) reviewing the difficulties associated with computing cartel overcharges and (ii) checking whether the fines levied on convicted firms are in line with these overcharges. We employ three methodologies to compute these overcharges. We find cartel overcharges estimates might be quite sensitive to its assumptions, but apart from differences in differences models with quadratic and cubic trends the fines are in the middle of the range of cartel overcharge estimates. This indicates that the fines are in line with cartel overcharges, but it is recommended to use a set of estimates produced by different methods to ensure their adequacy.
\end{abstract}

\section{Keywords}

Cartel overcharge. Cartel prevention. Antitrust.

\section{Resumo}

O sucesso na aplicação da lei de defesa da concorrência no que diz respeito à punição de cartéis depende de procedimentos sólidos de investigação e punição eficaz. No entanto, a legislação existente apenas fornece direção para o cálculo das multas de cartel com base na receita de vendas, ainda que tais multas não possam ser inferiores ao ganho de cartel. Usando dados de um caso real, temos dois objetivos no presente artigo: (i) revisar os desafios associados com o cálculo de estimativas de sobrepreço de cartel e (ii) investigar se as multas aplicadas à firma estavam de acordo com o valor do sobrepreço de cartel. Utilizamos três metodologias para

- This paper is a revised version of CADE's working paper 002/2006 "Prevenção Ótima de Cartéis: o caso dos peróxidos no Brasil", part of results from the PNUD project - Evaluation of Damages Caused by the "Peroxides Cartel", CADE/PNUD. We would like to thank the editor and three anonymous referees for comments and suggestions. Claudio Lucinda thanks the support from CNPQ funding Productivity in Research, level 2. The authors are responsible for opinions expressed, without implying CADE or any other public completion authority.

1 Professor - Universidade Federal do Espírito Santo (UFES) - Departamento de Economia - Grupo de Pesquisa em Econometria (GPE).

Endereço: Av. Fernado Ferrari, 514 - Campus Universitário - Goiabeiras - Vitória/ES - Brasil. CEP: 29075-910 - E-mail: renato.seixas@ufes.br -ORCiD: http://orcid.org/0000-0002-0510-5181.

2 Professor - Univ. de São Paulo - Faculdade de Economia, Administração e Contabilidade (USP-FEA). Endereço: Av. Prof. Luciano Gualberto, 908 - Cidade Universitária - São Paulo/SP - Brasil. CEP: 05508-010 - E-mail: claudiolucinda@usp.br - ORCiD: http://orcid.org/0000-0002-2190-9497. Recebido: 31/01/2017. Aceite: 04/10/2018.

(c) (i) (\$) Esta obra está licenciada com uma Licença Creative Commons Atribuição-Não Comercial 4.0 Internacional. 
estimar estes sobrepreços. Os resultados indicam que as estimativas são sensíveis às hipóteses utilizadas, mas exceto por modelos diferenças em diferenças com tendências quadráticas ou cúbicas, as multas estão aproximadamente no ponto médio das estimativas. Isso indica que as multas estão em linha com os sobrepreços de cartel, mas se recomenda o uso de um conjunto de estimativas produzidas por diferentes métodos para se ter maior segurança de sua adequação.

\section{Palavras-Chave}

Danos por cartel. Prevenção a cartéis. Antitruste.

\section{JEL Classification}

L13, L41, L65.

\section{Introduction}

One of the most important aspects of competition law enforcement is cartel prosecution. Success of this task is dependent on the investigation procedures and the effectiveness and strength of punishment when cartels are discovered.

This paper employs data from a real case, ${ }^{1}$ the hydrogen peroxide cartel, to address two questions. The first one is to review the pitfalls associated with estimating cartel overcharges in the context of a real case, i.e., carrying out the analyses in a way consistent with the time and data constraints econometricians in competition offices face in a real setting that might make unfeasible more complex analysis suitable for an academic research project. ${ }^{2}$ The second question refers to how the overcharge estimates compare with the actual fines levied in a specific case.

We study the the hydrogen peroxide cartel, in which two firms - Degussa ${ }^{3}$ and Peróxidos do Brasil (PBR) - were convicted for conspiring to maintain high prices in the hydrogen peroxide market in Brazil. The conspiracy took

1 The original documents from the case file are not publicly available. We were given access to them under a confidentiality agreement that prevents us from making the dataset available for replication. However, graphic display that illustrates the market behavior was allowed. We will be glad to share the original dataset as soon as the confidentiality is lifted.

2 For instance, estimation of damages based on models of dynamic games (Doraszelski \& Pakes, 2007).

3 Degussa is the controlling firm of Bragussa, which is the actual producer of hydrogen peroxide. In 2006, Degussa was acquired by RAG group, which later on was reorganized as Evonik Industries AG. Currently, the firm is denominated Evonik-Degussa in Germany, or simply Evonik in Brazil. To maintain consistency with the case file, we use the name Degussa throughout the paper. 
place between 1995 and 2004, when Degussa settled a leniency agreement ${ }^{4}$ with CADE looking for reduced penalties. The whole prosecution took about 8 years and the firms involved were convicted in 2012. Using confidential data collected by CADE during the investigation, we estimate the value of overcharges imposed by the cartel and compare the estimates with the fines applied to the firms at the time of conviction.

The economics literature (Landes 1983) indicates as the optimal punishment for a price fixing case the sum of the monopoly transfer and the share of the deadweight loss borne by customers, provided enforcement is costless and all price fixing agreements are caught. Thus, comparing the fine levied by CADE and the losses from the cartel price overcharge is a "pragmatic" approach to assess the size of cartel fines. We consider this a "pragmatic" approach because there are economic issues (such as the evaluation of the deadweight loss size and the proportion of the overcharge passed on to downstream consumers) which are not considered here and in themselves deserving a separate paper for each one. ${ }^{5}$ Thus, those overcharges can best be seen as a lower bound for fines.

The estimates presented here can also help in terms of policy evaluation. The Brazilian competition law (12.529/11) sets fines for companies found guilty of participating in a price fixing conspiracy. They are liable to fines between $0.1 \%$ to $20 \%$ of gross sales revenue in the affected sector of either the firm or the group during the fiscal year prior to the beginning of investigations. However, the same law also states the fine must not be below the price fixing gains. Law 12.529 superseded Law 8.884/94, which was in force during the final ruling of this case, and had a somewhat similar text on the matter. This law stated firms convicted of price fixing conspiracies were liable to fines between $1 \%$ and $30 \%$ of net sales revenue, also provided this value was not below the gains from price fixing.

Apart from that caveat, all guidelines for computing cartel fines in such laws do not prescribe how these overcharges should be computed. Fines based on sales revenue have the advantage of being more transparent to all parties involved in a cartel case, not requiring any sort of assumption on how to measure actual economic profits from such course of action. However, such a loose relation between the fines levied and the gains from

\footnotetext{
4 http://en.cade.gov.br/topics/leniency-program

5 Also, we do not dicuss the issue of the destination of fines levied, i.e., whether they should be retuned to the affected parties as compensation or not.
} 
cartel activity lead us to question whether they could act as a deterrence to cartel activity. Thus, comparing the fines with the overcharges can also be helpful in checking whether an application of sales based fines is in line with the benefits from cartel activity to its members

The paper is structured in six sections. After this introduction, we revisit the definition of cartel damages, cartel overcharges and the literature on fines determination for cartels. The third section describes the hydrogen peroxide market in Brazil and the cartel prosecution that convicted the firms. The fourth section estimates cartel overprices caused by the cartel using three methodologies: a reduced-from, before and after and difference in differences approach, and a structural model. The fifth section compares the estimated overprices to the total fines applied to the convicted firms and the sixth section concludes.

\section{Cartel Damages, Overcharges and Fines}

From a strictly legal standpoint, damages can be defined as "[a] pecuniary compensation or indemnity, which may be recovered in the courts by any person who has suffered loss, detriment, or injury, whether to his person, property, or rights, through the unlawful act or omission or negligence of another" (Black 1991). This definition, by using terms as "compensation" for some "damage", calls for a counterfactual analysis in the spirit that economists are used to perform in other types of evaluation. A starting point for computing damages is by computing the estimated difference between the price consumers payed during cartel operation and a counterfactual price that would have been charged "but for" the cartel. Since we don't observe this "but for" price, some sort of estimate is necessary and that is where economic analysis is fundamental. ${ }^{6}$

${ }^{6}$ Even though this is a starting point, it is not an ending point. There several issues such as the ability of injured parties to pass on the price increases to ultimate consumers and the amount of lost sales due to increased prices. 
Our goal is then to estimate the counterfactual price, the one that would have prevailed in the absence of the cartel. We can use a standard price-quantity diagram to understand the role of this exercise and how it is applied in the calculation of different measures of cartel losses. Figure 1 illustrates observed price and quantity set by the cartel, $p^{m}$ and $q^{m}$, and the price and quantity that would have prevailed under competition, $p^{c}$ and $q^{c}$. From an economic point of view, the damages (welfare losses) caused by the conspiracy would be represented by area $p^{c} p^{m} A C$. To get a financial value for this area one would need to provide some estimate of the demand function to find some estimate of the competitive quantity $\left(q^{c}\right)$ and the competitive price $\left(p^{c}\right)$. However, time constraints found in legal cases could make it common to estimate only the competitive price and use observed quantities as a basis cartel losses. This approach leads to cartel losses depicted in the shaded area $p^{c} p^{m} A B$ in Figure $1 .^{7}$

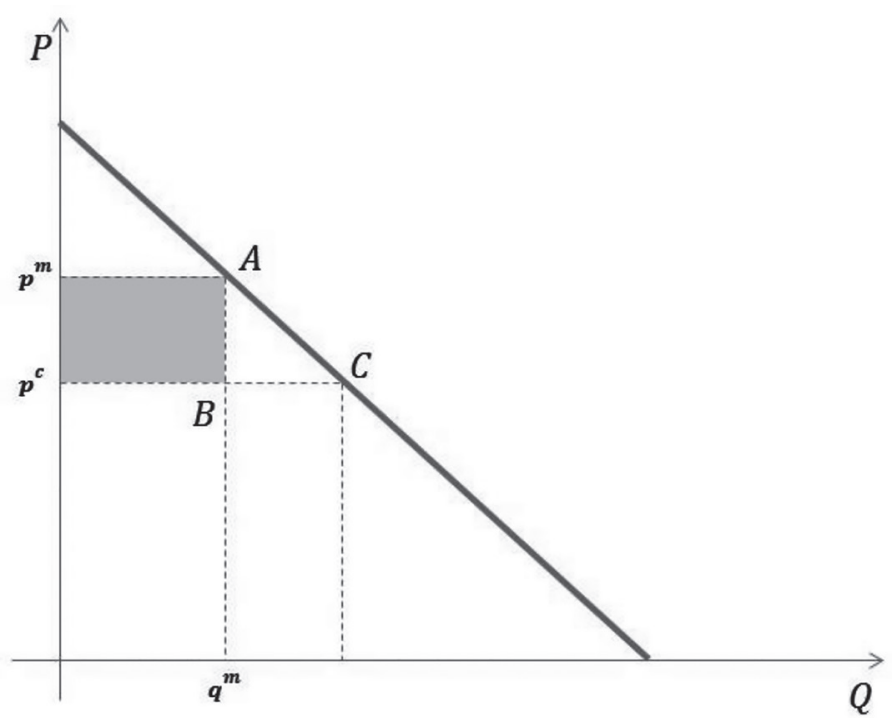

Figure 1 - Cartel Overcharges

Source: own elaboration

7 In technical terms, this represents the transfer of surplus from consumers to producers following the price elevation by the cartel. Area $A B C$, which completes the total damage, represents the loss in economic efficiency (dead-weight loss) related to units that are not sold due to the price increase. 
Algebraically this area is equal to:

$$
A=\left(p^{m}-p^{c}\right) \times q^{m}
$$

In Equation 1, the term in parenthesis $\left(p^{m}-p^{c}\right)$ is denoted the "overcharge". Frequently, the overcharge can be expressed as a percentage over the observed price, $\left(p^{m}-p^{c}\right) / p^{m}$, or in relation to the counterfactual price, $\left(p^{m}-p^{c}\right) / p^{c}$ (OXERA 2009). It is important to note that this measure understates the total welfare losses caused by a cartel in a market. First, it ignores the magnitudes of the deadweight loss represented by area $A B C$ in Figure 1. Another important source of distortion occurs when the product in question is an intermediary and the price increase is then passed along the production chain until it reaches the final consumer. In those cases, if there is market power in the downstream chain, the losses can be amplified due to double marginalization. ${ }^{8}$

This fact leads to an important difference in terminology between the legal and economic communities in antitrust. Economists tend to define cartel damages as the total welfare loss caused from the cartel in action, whereas the legal definition above is much less clear about the other parts (downstream effects and deadweight loss) are part of the cartel losses. In the present paper, the focus will be on the overcharges themselves, and not on damages.

The empirical evidence on cartel effects shows that those can be significant (Posner 2001; OECD 2002; Werden 2003; Levenstein \& Suslow 2004). The more comprehensive study available (Connor \& Lande 2008) performs a meta-analysis of evidence raised in different fields of social sciences containing 674 observations of cartels documented between 1780 and 2004, finding an average overcharge equivalent to $23 \%$ of the observed price. ${ }^{9}$ An extension of that study (OXERA 2009) adds 350 observations and applies some criteria to restrict the sample, resulted in a total of 114 observations. ${ }^{10}$ The resulting distribution of overcharges relative to observed prices is shown in Figure 2.

8 As will become clear, this is the case in the hydrogen peroxide industry. However, we won't address this issue in this paper.

${ }^{9}$ Equivalent to $25 \%$ of the competitive price.

10 The selection criteria were: (i) cartels that started after 1960, (ii) cartels for which there was an estimate for the overcharge in the period when the cartel was active, (iii) studies where the method of damage estimation was clear enough and (iv) studies that were published in peer-reviewed academic articles or published book chapters. 


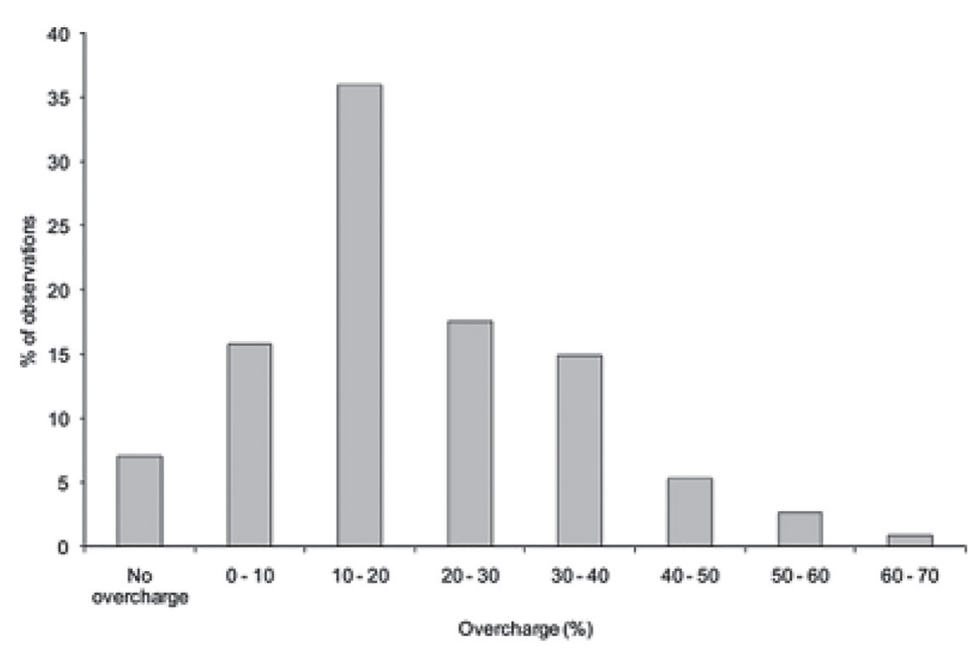

Figure 2 - Overcharges as a Percentage of Observed Prices Source: (OXERA 2009).

In $93 \%$ of the cases, cartels succeeded in imposing overcharges to the market. The mean overcharge found was about $20 \%$. International cartels had a mean overcharge greater than national cartels (26\% vs. 16\%). Cartels operating in the US and Canada had smaller overcharges than in other parts of the world (16\% vs. 23\%). Finally, illegal cartels had greater overcharges than legal ones (21\% vs. $17 \%)$

Specifically with respect to cartel punishment, the literature shows two main concerns in the calculation of fines: (i) prevention that other cartels are organized or stay in operation and (ii) compensation of victims (Connor \& Lande 2008). Each jurisdiction finds a different equilibrium between these two goals. It is important to notice the setting of fines is a separate task from computing overcharges, even though a value for cartel overcharges can be helpful in fine setting.

The current Brazilian law (12.529/13) limited fines to 20\% of sales in the year before the beginning of prosecution, adding that it should not be less than de advantage obtained from the cartel when this is possible to estimate. Besides, executives in charge of the cartel can be fined from $1 \%$ to $20 \%$ of the fines received by the firm. Other sanctions can be considered by CADE, such as: prohibition of parceling of fiscal debts, prohibition of 
contracting subsidized funds from state banks and prohibition of participating in public procurement processes. Finally, executives are also subject to criminal lawsuits that can result in convictions from 2 to 5 years in prison. ${ }^{11}$ The Brazilian jurisdiction also allows for the possibility of private recurring to courts for restitution of losses caused by cartel action.

At the time of this writing, the definition of cartel fines is a controversial subject in the Brazilian Antitrust Authority. In case 08012.002568/200551 , on a price fixing conspiracy in the market for natural gas in the state of Pará, northern Brazil, the commissioner assigned to the case proposed a fine based on an econometric study which she claimed was well within the bounds of applicable case law. In this case, she was seconded by only one other commissioner. Three other commissioners have filed dissenting opinions presenting estimates based only on percentages of net sales with different market definitions - and with lower fines.

Both sides in this controversy have good points, which give even more relevance to an empirical study as the present one. On a first glance, cartel fines based on a percentage of sales in a single year might be seen as leading to too small fines. However, since the percentage of these sales that actually accrue to the firm owners might be quite small, a large percentage of sales might be equal to the additional net profits from several years of a price fixing conspiracy. Besides, a rule based on net sales instead of net profits might be robust to different accounting standards on how net profits are computed. This gives predictability to the enforcement of the Law.

On the other hand, basing fines in a study specifically designed to measure price fixing gains also have benefits. First of all, it gives an estimate directly related to the infringement, which might give the right incentives in discouraging cartel activity. Besides, an estimate of cartel overcharges made by the Competition Authority could help increase the number of cases brought to courts by individuals and firms harmed by cartel activity, fulfilling the role of Competition Advocacy the Brazilian Competition Authority has. Fines based on losses inflicted are also common in other areas in Brazil. For instance, Law 13.506/17, which sets the framework for fines by the Brazilian capital markets regulator, stipulates fines can be based on twice the losses caused by the defendant.

${ }^{11}$ Similar provisions were also in the previous Brazilian Competition Law (8.884/94). 
In any case, some light must be shed on whether sales based fines as in Law 12.529/13 are close to measures of cartel overcharges, which makes the present study specially relevant. We aim by doing so at looking at a specific case, to be discussed below.

\section{The Hydrogen Peroxide Cartel}

Hydrogen peroxide is mainly used as a bleaching agent in the pulp and paper industry, with other applications including chemical processes, treatment of industrial and residential effluents, and textile industry. ${ }^{12}$ Information from the case file reveals the main clients of one of the cartel firms are in the pulp and paper industry (56\%), chemical (8\%) and textiles $(8 \%)$. Even though there are other bleaching agents, hydrogen peroxide has some advantages, such as: lower cost, better whitening quality, reduction of effluents colors and lower environmental impact. On the production side, the main inputs used are hydrogen - produced from naphtha - natural gas, electricity, oxygen - produced by compression of atmospheric air - anthraquinone and solvents.

The Brazilian market has the same large international players, Solvay (whose Brazilian subsidiary is Peróxidos do Brasil or PBR) being the largest one with total capacity of more than a million tons/year, more than twice the second largest player, Evonik-Degussa. In Brazil, the industry started in 1974 when PBR installed its first production plant. Since 1997, its activities are concentrated in Curitiba/PR. Until the 90's, PBR was the sole producer and virtual monopolist in Brazil. From 1992 on, when Degussa started to consistently sell in the Brazilian market through imports, ${ }^{13}$ the industry evolved as a duopoly, with market shares stabilizing at $60 \%$ to PBR and 40\% for Degussa. Only in 2011 a new player came to scene when the Turkish group Garipoglu inaugurated its production plant, Peroxy Bahia, in Camaçari/BA, with capacity of 40,000 tons/year. By 2012 the shares in capacity, as available in the company's websites, were: $62 \%$ for PBR, 24\% for Degussa and 14\% for Peroxy Bahia.

${ }^{12}$ Most of the information in this section was gathered from the case file. We try to keep information from the specific firms as unidentified as possible.

${ }^{13}$ In 1992, Degussa built a system of tanks in Brazil that allowed it to receive and store large amounts of hydrogen peroxide and build a portfolio of local clients. 
Although imports can be potential competitors, they face high costs and risks associated with large distance transportation. Besides, regular supply involves installing specific storage equipment at the customer facilities, ${ }^{14}$ which gives an additional competitive advantage to local producers. Imports were greater or about the same as exports in 1997 and 1998, when Degussa was starting its activities in Brazil through imports. Since installed capacity is larger than total domestic demand, firms have incentives to export as way to explore economies of scale in production. ${ }^{15}$

The combination of product and market characteristics shape the competitive strategies followed by market participants. Very briefly, the competitive environment in the hydrogen peroxide industry can be summarized in the following points:

1. Hydrogen peroxide is a homogeneous product, with no substitutes, with price being the main strategic variable;

2. Transportation costs and operational risks require installation of dedicated equipment at client premises, making physical proximity from clients a big advantage;

3. As a reflection of 2, long-term supply contracts are common practice, making it difficult for a new entrant to gain market share;

4. Demand is concentrated in the pulp and paper industry;

5. Large dispersion in production capacities $(40,000$ to 180,000 tons/ year).

By the end of January 2004, Degussa's executives started negotiating a leniency agreement with competition officials at the Secretariat of Economic Defense from the Ministry of Justice (SDE/MJ). They sought to obtain lower fines and reduced legal sanctions as a result from collaborating with the investigation. With its executives negotiating an agreement with the Brazilian Competition Authority, Degussa stopped responding to PBR requests for meetings in Brazil after February, 2004.

\footnotetext{
${ }^{14}$ It is not by chance that production units currently in operation in Brazil are located close to pulp and paper plants in the states of Paraná, Espírito Santo and Bahia.

15 Also, there are only two other production plants in South America in Argentina and Venezuela that are smaller than the Brazilian counterparts.
} 
The leniency agreement was celebrated in May 2004 between Degussa, its executives and competition authorities and public attorneys in charge of criminal investigation. In that agreement, the executives presented internal documents that proved the existence and operation of the cartel and elaborated a document titled "History of Infringements" with detailed information on meetings and procedures for the cartel functioning.

The investigation started right after the agreement and, in June 2004, a dawn raid operation was set at the companies' headquarters to collect additional information and evidence of conspiracy. The lawsuit began in September 2004 and investigations lasted until 2012, when PBR and its executives were convicted by the Brazilian Competition Authority, under the terms of Law 8.884/94. They set a fine at 30\% of Brazilian net sales for the last year prior to Degussa leniency agreement, corrected by the interest rate of short term Brazilian government debt. The calculation of the fines applied to PBR is detailed in Table 1.

Table 1 - Calculation of Fines

\begin{tabular}{ll}
\hline Sales in 2003 & $\mathrm{R} \$ 187.737 .809,87$ \\
Discount 1 - Returns and Allowances & $\mathrm{R} \$ 11.144 .679,83$ \\
Discount 2 - PIS/COFINS & $\mathrm{R} \$ 16.866 .067,76$ \\
\hline Net sales in 2003 & $\mathrm{R} \$ 159.727 .062,28$ \\
Updating factor & 2,0269870000 \\
Updated net sales & $\mathrm{R} \$ 323.764 .678,79$ \\
Percentage of fine & $30 \%$ \\
\hline Final value of fine & $\mathrm{R} \$ 97.129 .403,64$ \\
\hline \hline
\end{tabular}

PBR executives were also personally liable for additional fines, according to Law 8.884/94. In the next section, we will present several methodologies to assess cartel overprices to compare with this amount.

\section{Estimating Cartel Overcharges}

We estimate cartel overcharges, as defined in section 2, using three approaches: a reduced form "before/after" analysis, a reduced form "difference in differences" and a structural model. The methods are based on 
econometric techniques, which set them apart from techniques based on accounting data only, for instance. However, they rest on very different behavioral assumptions. Both "differences in differences" and "before/ after" are agnostic about the competitive environment that would have prevailed without the cartel, whereas the structural model requires an explicit assumption on what would be the model that reflects the competitive behavior of firms without the cartel (Bertrand, Cournot, etc.).

Those differences also reflect in the data requirements for each method. Structural models require information on prices, quantities sold and data on demand and cost shifters. The other approaches require information on prices, as well as assumptions on markets and time periods when the cartel was active or not. The choice among these alternatives is highly context specific and could not be ranked in terms of suitability without knowing the availability and quality of data in a given case. Initially we will discuss our dataset, assembled as a combination of information from case files and publicly available information.

\subsection{Dataset}

Data on hydrogen peroxide market in Brazil were gathered from the case file that contained detailed information regarding revenues, prices and volume of sales between July 1997 and May 2004, a total of 83 months. From the information in the previous section, it is likely that the cartel end would be reflected in market variables at some point between January 2004 and May 2004.

After manually scraping the PDF case files, we were able to construct four time series of average prices for PBR: "ex-works" ${ }^{16}$ domestic price, delivery domestic price, export "ex-works" price and export delivery price. The information on PDF case files was originally collected in a dawn raid in PBR offices, which indicates that, even with a legal authorization for searching, all relevant data might not be available.

Information of prices and revenues were in nominal terms and were deflated with the Brazilian wholesale price index (IPA-IBGE). Figure 3 shows the evolution of the four series, which have missing observations and the

16 Price at the plant gate. 
most complete one refers to the domestic delivery price, which has missing observations for the period June-December of 2003. Yet, it is possible to note that domestic prices are systematic larger than the corresponding export prices.

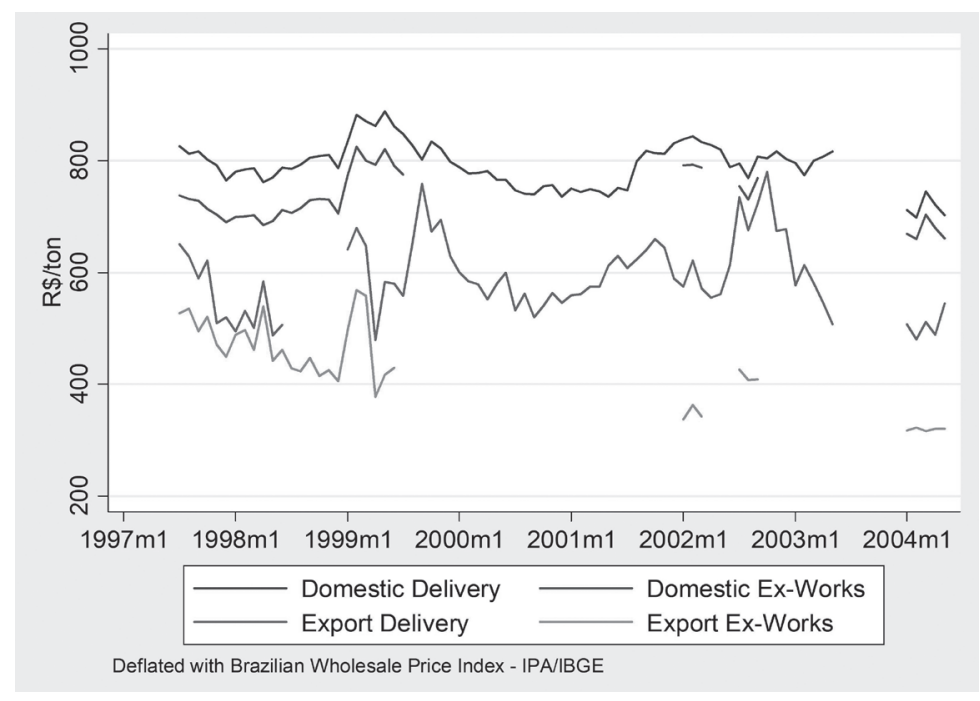

Figure 3 - PBR Prices

Source: case file.

We would like to use ex-works prices to estimate the overcharge, since this is net of transport costs, but the domestic ex-works price series has 47 (56\%) of missing observations. Nevertheless, ex-works and delivery prices are highly correlated: in the 29 months that have information for both prices we find a correlation of 0.95 . Hence, we opted to fill the missing points using a linear projection from delivery prices ${ }^{17}$ and a quadratic trend. ${ }^{18}$ Figure 4 shows the resulting series used for estimation. ${ }^{19}$

\footnotetext{
${ }^{17}$ The delivery price series also has 6 months of missing observations that were filled using a similar procedure and a forecast for revenues in 2002 and 2003. All results are available upon request.

${ }^{18}$ Model estimates are available upon request.

${ }^{19}$ We use the observed domestic ex-works prices, with missing observations replaced by the estimated price.
} 


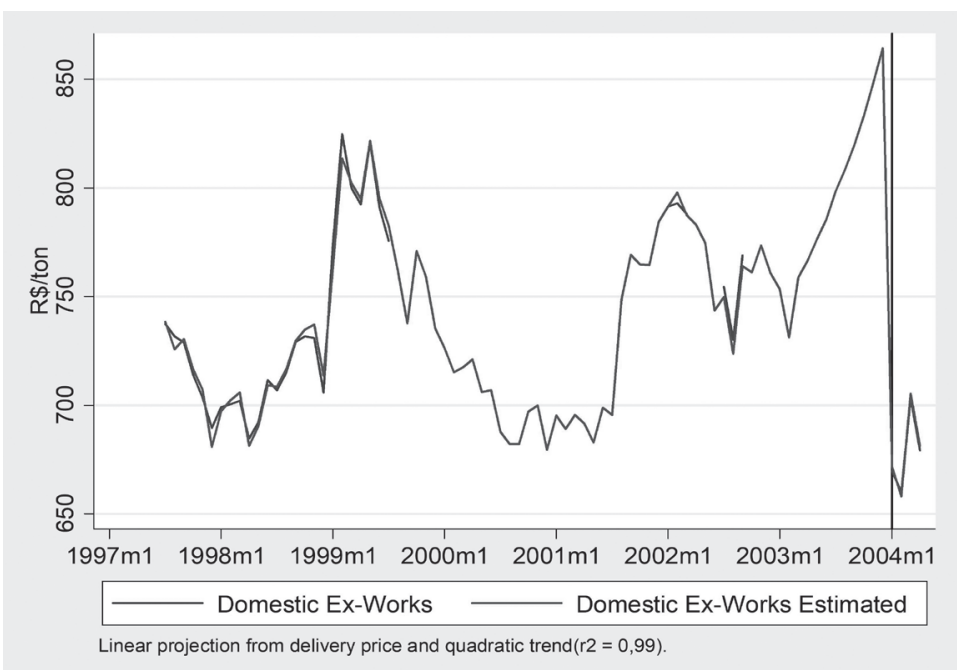

Figure 4 - Ex-Works Prices (observed vs. estimated)

Source: case file

Besides prices and quantity data, we also gathered series of public available variables that can represent demand and cost shifters. For demand shifters, we used the index of industrial production for pulp and paper. For cost shifters we used the price of naphtha, average electricity price for industries, and industry real wages.

International prices for Napthta in the spot market of north-western Europe are expressed in USD and are available at the INSEE website, ${ }^{20}$ and average electricity prices are from the National Electric Energy Agency and were available at the IPEADATA website. Real wages data for industry are from Foundation for Economic Resarch (FIPE) and are available for the São Paulo region.

We also used information on hydrogen peroxide markets in South America and the USA, as counterfactual markets in the difference in difference models. ${ }^{21}$ For South America, price series were assembled from statistics on quantity and value of exports available in from the AliceWeb system

${ }^{20}$ https://www.insee.fr/en/statistiques/serie/001641576?idbank=001641576

${ }^{21}$ Details on why those markets were chosen are given below. 
of the Ministry of Development, Industry and Trade. The original sales data are in nominal dollars and were converted to Brazilian Reais and then deflated using the IPA-IBGE index. For demand shifters we used information for quarterly GDP. For the US market, hydrogen peroxide average monthly prices were taken from Bloomberg (US cents/pound). Wage data come from the BLS and refer to average earnings for workers in the chemical industry (NAICS 3251). Data on electricity costs were obtained from the US Energy Information Administration and on naphtha international prices from the National Institute of Statistics and Economic Studies. All values were converted to Brazilian Reais and deflated using the IPA-IBGE. From this dataset our econometric analyses were carried out. The first one is a reduced form analysis which practitioners call "before and after analysis".

\subsection{Before and After Analisys}

The reduced form approach (Baker \& Rubinfeld 1999) estimates an equation that relates prices to demand and supply shifters and dummy variables that capture changes in the behavior of market participants. This approach is based on the notion that the estimated equation is a result of some structural model for demand and supply relations that determine market equilibrium. Changes in the behavioral equations (e.g. as a result of the end of a cartel) are reflected as changes in the coefficients of the estimated equations that are captured by dummy variables.

One way to estimate cartel overcharges uses the affected market, or the firms participating in the cartel, and compare the evolution of prices during cartel operation with periods of "normal" competition, i.e., when the cartel is not operating. This approach is also known as "before $v s$. during $v s$. after" analysis. The econometric model we use to implement the analysis is represented by Equation 02. It uses time series data to estimate a relationship between market price $\left(p_{t}\right)$, cost and demand shifters $\left(X_{t}\right)$ and a dummy variable $\left(D_{t}\right)$ that is equal to one in time periods of cartel and 0 otherwise. The coefficient $\delta$ represents the cartel overcharge, i.e., the difference between the cartel price and the competitive price.

$$
p_{t}=\alpha+\beta X_{t}+\delta D_{t}+\epsilon_{t}
$$


The inclusion of additional explanatory variables controls for other market influences that might have affected prices simultaneously to the conduct, like cost or demand shocks that can cause price increases that would be erroneously attributed to the cartel.

The advantage of this analysis is that it uses the same units (firms or markets) that were affected by the cartel to estimate the counterfactual price. Hence, the counterfactual is not contaminated by systematic and unobservable differences across markets that might confound a cross-sectional comparison of markets/firms affected and not affected by the cartel.

A big challenge concerns the determination of the period when the cartel operated (beginning and end) as well as the baseline period of normal competition over which to make the comparison. The analysis can be done comparing time periods before the cartel starts and after the cartel is implemented or time periods when the cartel is active and after its breakdown. Each of these choices has merits and drawbacks. The first case (before/during) has the advantage of using as a baseline a period when conduct is not contaminated by the cartel that, probably, reflects better a non-cooperative pricing by the firms. On the other hand, it can be difficult to identify the exact moment when the cartel started operating: firms can adhere gradually over time and different regions and additional firms might gradually adhere as well. The second case (during/after) has the advantage of being more recent, which facilitates data collection. On the other hand, in periods after dismantling, it's possible that the market takes some time until it reaches a non-cooperative equilibrium, since firms might still know a lot of information about their rivals (OXERA 2009) or they might have incentives to keep elevated prices to strategically mask evaluation of cartel overprices conducted in investigation (Harrington, Jr. 2004).

Our analysis uses the post-cartel phase, which we assume starts in January 2004, as the competitive period, as opposed to the cartel period that we assume lasted until December 2003. This choice rests on information in the case file that shows that the last meeting between executives from Degussa and PBR took place in that month for a performance review of the year of 2003 and in that same month, Degussa started negotiations for the leniency agreement. Another practical reason for that choice is that the information in the dataset starts in 1997, when the cartel was already operating. Figure 5 shows the evolution of price and displays a sharp 
drop in January 2004 that is maintained in the following months, which we consider as additional indication that the cartel ceased operating right after the negotiations of the leniency agreement started. Hence, variable of interest takes the value of 1 for time periods without the cartel and zero for time periods when the cartel was operating (before January of 2004). Therefore, we expect to find a negative estimate for the coefficient of interest $(\delta)$ in equation 2, that captures the price drop after the end of the cartel. Table 2 shows results from our most preferred specifications for Equation 2.22

Table 2 - Overcharge Estimates (TS): Depend Variable: PBR Price

\begin{tabular}{lcccccc}
\hline & $(1)$ & $(2)$ & $(3)$ & $(4)$ & $(5)$ & $(6)$ \\
\hline $2004 / 01$ & $-136.319^{* *+*}$ & & $-162.232^{* * *}$ & & $-156.207^{* * *}$ & \\
& {$[32.444]$} & & {$[19.087]$} & & {$[19.113]$} & \\
$2004 / 02$ & & -88.891 & & $-114.526^{*}$ & & $-105.817^{*}$ \\
& & {$[45.164]$} & & {$[43.970]$} & & {$[46.054]$} \\
Constant & $749.323^{*}$ & $1108.925^{* *}$ & $4076.147^{* *+}$ & $4319.399^{* * *}$ & 9758.565 & 12983.111 \\
& {$[281.801]$} & {$[372.856]$} & {$[545.235]$} & {$[609.372]$} & {$[6256.586]$} & {$[6913.980]$} \\
\hline $\mathrm{N}$ & 65 & 65 & 65 & 65 & 65 & 65 \\
r2 & 0.710 & 0.635 & 0.873 & 0.785 & 0.876 & 0.793 \\
Linear Trend & yes & yes & yes & yes & yes & yes \\
Quadratic Trend & no & no & yes & yes & yes & yes \\
Cubic Trend & no & no & no & no & yes & yes \\
\hline
\end{tabular}

Robust standard errors in brackets.

${ }^{*} \mathrm{p}<0.05,{ }^{* *} \mathrm{p}<0.01,{ }^{* * *} \mathrm{p}<0.001$

Linear models with trends (linear, quadratic and cubic) and month seasonal dummies. Controls: real wages, pulp and paper production,

Sample: 1999/01-2004/05

For the sake of comparison, we use two different dates for the end of the cartel: January and February of 2004. For demand and cost shifters we use the index of industrial production for pulp and paper, the price of naphtha, average electricity price for industries, and industry real wages. We also include different specifications of deterministic trends (linear, quadratic and cubic) to capture possible non-linarites in the behavior of prices.

The estimated coefficients show a significant decrease in prices in January of 2004 between R $\$ 136.3 /$ ton and $\mathrm{R} \$ 162.2 /$ ton. Setting the date of the cartel end in February reduces the effect and makes it non-significant. ${ }^{23}$

22 The complete results are available upon request.

${ }^{23}$ We also tested for cartel ends in 2004/03 and 2004/04 with insignificant results. As robustness 
Relative to the average price of $\mathrm{R} \$ 753.62 /$ ton before the cartel end, this represents a decrease between $18 \%$ and $22 \%$. Hence, the magnitude of the overcharge is also of economic significance. Applying the estimated overcharges to the observed quantities between 1998 and 2004, we find an average of $\mathrm{R} \$ 174.65$ million for the implied cartel overcharge (Eq. 01).

\subsection{Difference in Differences}

The difference in difference model (Angrist \& Pischke 2009) expands the reduced form analysis by using longitudinal data on different markets in time periods with and without cartel operation. Concretely, the model compares the evolution of prices in markets affected vis a vis in markets not affected by the cartel. Therefore, we use the non-affected market as a counterfactual for what would have been the evolution of prices in the affected market, had it not been affected by the cartel. The econometric model that implements the difference in difference methodology has the following general form:

$$
p_{i t}=\gamma_{i}+\lambda_{t}+\delta D_{i t}+\theta X_{i t}+\epsilon_{i t}
$$

In Equation 3, $p_{i t}$ represents observed price in market $i$ at time period $t, \gamma_{i}$ a market fixed effect and $\lambda_{t}$ a fixed effect for the period when the cartel was active. $D_{i t}$ is a dummy variable that equals 1 for markets and time periods when the cartel is in operation and the coefficient $\delta$ is the overcharge (price difference) caused by the cartel. The variable $X_{i t}$ represents cost and demand shifters that also affect observed prices in each market. The central assumption that allows us to identify the parameter $\delta$ as the causal effect of interest is that prices follow the same trend in the absence of the change in conduct. This change induces a deviation from the common trend in one of the markets that can be attributed to the cartel. Other differences in prices across markets that are due to non-observed factors that are fixed over time are captured by the market fixed effects.

Besides the time period when the cartel is active, the difference in difference method requires the definition of the non-affected markets that are used as

check, we tested for cartel end before January 2004, between July and December of 2003, with insignificant results. All those additional tests can be made available upon request. 
counterfactuals. Our analysis uses the markets in South America - except Brazil - and the USA. The evidence in the case files points that the cartel operated in the Brazilian territory, which motivated the definition of the relevant market as Brazil only. This evidence, coupled with geographical and economic proximity of countries makes South America as a good candidate for counterfactual market. The choice of the US market is justified by two reasons. First, the use of an additional counterfactual allows checking for the robustness of estimates as it brings more information to the analysis. Second, a similar cartel operating in the US market was uncovered and punished in 2001, years before the Brazilian cartel. Hence, it's plausible to assume that, from 2002 onwards, the US market behaved in non-cooperative competitive conditions.

Figure 5 shows the evolution of hydrogen peroxide prices for the three markets chosen for the analysis. The sharp drop in prices in the Brazilian market in January 2004, while the other prices follow a smooth trajectory, allows us to identify the effect of the end of the cartel and the overcharge that was caused by the conduct.

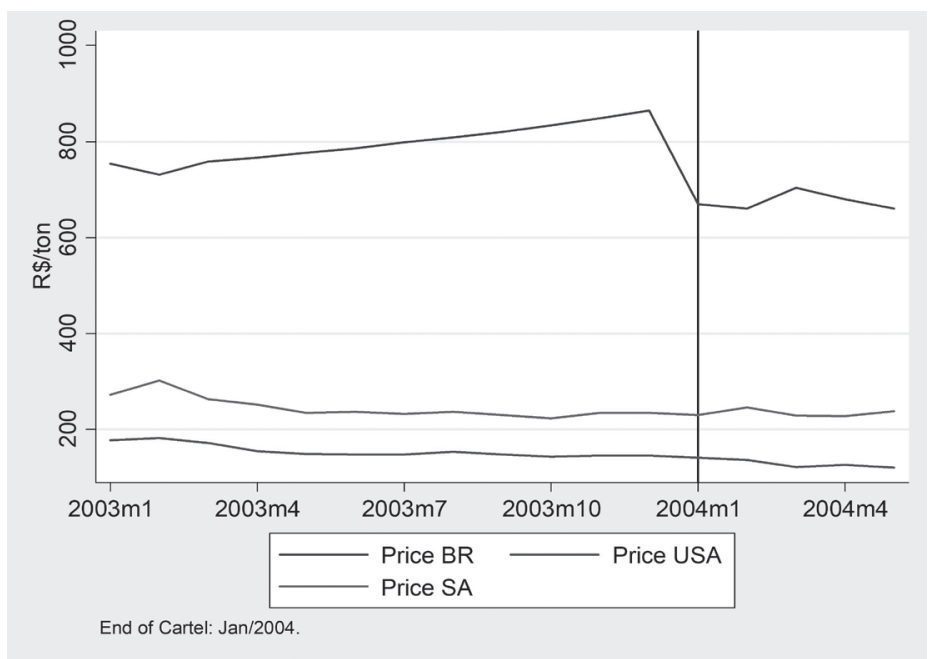

Figure 5 - Hydrogen Peroxide Prices

Sources: case file (BR), Bloomberg (USA) and AliceWeb (SA).

Before the computation of cartel overcharges, we conduct some tests to check on the assumption of the difference in difference model: prices follow similar trends in all markets and the counterfactual markets are 
not affected by the end of the conduct. ${ }^{24}$ Visual inspection of Figure 7 suggests that prices in Brazil follow an upward trend while in the other markets it follows a downward one. Statistical analysis confirms that. We control for those differences by adding market specific trends, in different specifications (linear, quadratic and cubic), to the estimated model. We also check if there is any change in the behavior of prices in the counterfactual markets, after controlling for demand and cost shifters, after January 2004. ${ }^{25}$ We find that South America and US markets do not respond consistently to the variable that indicates the end of the cartel. In the first market, prices respond positively. In the US, the sign of the variable is not constant across different specifications. Hence, we conclude that South America and US can be valid choices for counterfactuals for the Brazilian market.

Table 3 shows results for Equation 3. The variable "cartel" corresponds to an interaction between a dummy for Brazil and a dummy for January 2004 onwards. ${ }^{26}$ The models were estimated for each counterfactual market separately and using all together.

Table 3 - Overcharge Estimates. Dependent Variable: Price

\begin{tabular}{|c|c|c|c|c|c|c|}
\hline Model & Counterfactual & Cartel & S.E. & Trend & $\mathrm{N}$ & $r^{2}$ \\
\hline (1) & SA & $-75.178^{* * *}$ & [12.806] & lin. & 58 & 0.986 \\
\hline (2) & SA & $-148.329^{* * *}$ & [20.088] & lin. ${ }^{1}$ & 58 & 0.99 \\
\hline (3) & SA & $-280.023^{* * *}$ & [25.357] & quad. ${ }^{1}$ & 58 & 0.995 \\
\hline (4) & SA & $-207.064^{* * *}$ & [23.358] & cub. ${ }^{1}$ & 58 & 0.996 \\
\hline (5) & USA & $-59.855^{* * *}$ & [12.144] & lin. & 58 & 0.992 \\
\hline (6) & USA & $-140.110^{* * *}$ & [18.248] & lin. ${ }^{1}$ & 58 & 0.995 \\
\hline (7) & USA & $-242.083^{* * *}$ & [18.642] & quad. ${ }^{1}$ & 58 & 0.998 \\
\hline (8) & USA & $-195.923^{* * *}$ & [21.698] & cub. ${ }^{1}$ & 58 & 0.998 \\
\hline (9) & SA/USA & $-67.516^{*}$ & {$[6.837]$} & lin. & 87 & 0.989 \\
\hline (10) & SA/USA & $-144.220^{* * *}$ & [3.713] & lin. ${ }^{1}$ & 87 & 0.993 \\
\hline (11) & SA/USA & $-261.053^{* *}$ & [17.476] & quad. ${ }^{1}$ & 87 & 0.996 \\
\hline (12) & SA/USA & $-201.493^{* * *}$ & {$[5.236]$} & cub. ${ }^{1}$ & 87 & 0.997 \\
\hline
\end{tabular}

1: market specific trend

Models (1)-(8): Robust standard errors in brackets.

Models (9)-(12): standard errors clustered at the market level.

${ }^{*} \mathrm{p}<0.05,{ }^{* *} \mathrm{p}<0.01,{ }^{* * *} \mathrm{p}<0.001$

Sample: 1999/01-2004/05

${ }^{24}$ We do not report the results for these pre-analysis due to space constraints but they are available upon request.

${ }^{25}$ Results are available upon request.

${ }^{26}$ The complete results, including controls and robustness checks are available upon request. 
The results show some variation on estimates of overcharge across specifications. For each counterfactual analysis (Brazil vs. SA, Brazil vs. US and all together), we estimate a model with a deterministic linear trend and a linear, quadratic and cubic market specific trends. Hence, for each counterfactual market we have four different specifications. All coefficients are significant and have the expected sign. The inclusion of market specific trends increases severely the magnitudes, indicating that controlling for different trends is quite important. Nevertheless, those estimates are closer to the ones obtained using the time series methodology of the last section.

The average overcharge estimate is $\mathrm{R} \$ 168.57 /$ ton with a range between $\mathrm{R} \$ 59.86 /$ ton (Brazil vs. US) and R $\$ 280.02 /$ ton (Brazil vs. South America). Relative to the average price of $\mathrm{R} \$ 753.62 /$ ton before the cartel end, this represents a decrease between $8 \%$ and 37\%. The South America market produces bigger estimates for the overcharge (average $\mathrm{R} \$ 177.65 /$ ton $^{27}$ ) compared to the US market (average R $\$ 159.49 /$ ton). ${ }^{28}$ Applying the estimated overcharges to the observed quantities between 1998 and 2004, we find an average of $R \$ 231.21$ million for the implied overcharge (Eq. 01).

\subsection{Structural Model}

The structural approach makes intensive use of oligopoly models to estimate directly the equations (supply and demand sides of the market) that determine industry equilibrium. The estimated equations are then used to simulate an alternative (counterfactual) market price that would have prevailed according to some specified non-cooperative (e.g. Cournot, Bertrand) equilibrium (OXERA 2009). The main advantage of this approach is that we do not need data for both periods of normal competition and of cartel behavior, and another market to serve as the counterfactual competitive benchmark. Also, the structural approach allows the researcher to estimate the complete welfare cost (area $p^{c} p^{m} A C$ in Figure 1) of the conspiracy. The main drawback of this approach is related to the need to specify a specific form of competition in the absence of the cartel. Alternative specifications can result in very different results and the

${ }^{27}$ Using a model with quarterly data that includes GDP, real wages and price of naphtha as controls, the average is $\mathrm{R} \$ 150,80 /$ ton.

${ }^{28}$ Using a model that includes real wages, electricity prices and naphtha as controls, the average is $\mathrm{R} \$ 160.74 /$ ton. 
choice requires very strong justification from the researcher. Such issues were already discussed in the literature, for instance in (Crooke, Froeb, Tschantz, \& Werden 1999) for the case of merger simulation or (Genesove \& Mullin 1998) for a specific application.

Estimation begins by choosing a specific specification for a system of equations that describe the demand side and a supply relation for the supply side. For the demand side, we use the following linear specification:

$$
Q=\beta_{0}+\beta_{1} P+\beta_{2} Y
$$

In Equation 4, $Q$ represents quantity of hydrogen peroxide, $P$ is price and $Y$ a demand shifter.

For the supply side, an important issue is the specification for the industry average marginal cost. We use the following linear function:

$$
C M g=\gamma_{0}+\gamma_{1} W
$$

In Equation 5, $W$ represents input costs. Hence we're assuming a constant marginal cost with respect to the quantity produced that implies that average costs are decreasing relative to the quantity produced. This is consistent with a fixed coefficients (Leontief) technology - which seems reasonable provided production of hydrogen peroxide depends on a chemical reaction. Besides, information from the case file indicates fixed costs accounts for about $1 / 3$ of total production costs. ${ }^{29}$ We experimented with richer specifications with not much success.

Equilibrium is characterized from the profit maximization problem of a firm in an imperfectly competitive industry. As such, the firm equates perceived marginal revenue to marginal costs to determine the quantity produced. Since $Q=\sum_{i} q_{i}$, and firm's $i$ revenue is given by $R_{i}=P(Q) Q_{i}$, marginal revenue is given by the following equation:

$$
M R_{i}=P+q_{i} \frac{\partial P}{\partial Q} \frac{\partial Q}{\partial q_{i}}
$$

${ }^{29}$ According to information contained in the case file. 
Multiplying the above expression by firm $i$ 's market share $\left(s_{i}\right)$ and summing over all firms we find an expression for "market wide" marginal revenue:

$$
\sum_{i} S_{i} M R_{i}=P+Q \frac{\partial P}{\partial Q} \sum_{i} S_{i} \frac{\partial Q}{\partial q_{i}} \frac{q_{i}}{Q}
$$

Summation in the left hand side of Equation 6 can be written as $\sum_{i} s_{i}^{2} \frac{\partial Q}{\partial q_{i}}=\lambda^{A}$ and represents the "aggregate" conjectural variation and characterizes industry conduct. So, for instance, if industry behaves as a Cournot oligopoly, then $\partial Q / \partial q_{i}=1$ and $\lambda^{A}$ equals the Herfindahl-Hirschman index of concentration (which in our case is equal to 0.5 , with both firms sharing equally the market). If the industry is perfectly competitive, $\lambda^{A}=0$, and if it behaves as a monopoly (or a perfect cartel), $\lambda^{A}=1$.

Using the linear demand to obtain a functional form for Equation 5, equating Equations 4 and 5, such that marginal cost equals perceived marginal revenue, and rearranging, we arrive at the following supply relation:

$$
P=Q \frac{\lambda^{A}}{\beta_{1}}+\gamma_{0}+\gamma_{1} W
$$

Equation 7 can be jointly estimated with Equation 4 and the parameter $\lambda^{A}$ can be recovered by dividing the coefficient on $Q$ in Equation 6 by the inverse of the coefficient on $Q$ in Equation 4. We implement this model using the quantity of hydrogen peroxide sold in Brazil for time period $t$, the hydrogen peroxide price per ton, the industrial index for cardboard production as a demand shifter $\left(Y_{t}\right)$ and labor cost, both contemporaneously as well as one period lagged as input price $\left(W_{t}\right)$ in the marginal cost equation. The estimation method used was Three-Stage Least Squares. ${ }^{30}$ Table 4 shows the results of joint estimation of Equations 3 (demand) and 6 (supply). The estimated models reject the hypothesis of perfectly competitive and Cournot behavior (in which the conduct parameter would be equal to the Herfindahl-Hirschman Index with both firms sharing equally the market). ${ }^{30}$ For the demand equation, we have a first stage F statistic of 82.49 , but not as large as the F stage for
the supply relation, which was 1.91 . 
Table 4 - Structural Estimation Results

\begin{tabular}{|c|c|c|}
\hline \multicolumn{3}{|c|}{ System Equations } \\
\hline & Demand & Supply \\
\hline \multirow[t]{2}{*}{ Price } & $-1,5217^{\star \star \star}$ & \\
\hline & $(-4,2227)$ & \\
\hline \multirow[t]{2}{*}{ Cardboard } & $33,8037^{*}$ & \\
\hline & $(2,4257)$ & \\
\hline \multirow[t]{2}{*}{ Wages } & & $-94,0909^{* \star *}$ \\
\hline & & $(-5,1859)$ \\
\hline \multirow[t]{2}{*}{ Quantity } & & $1,0213^{* * \star}$ \\
\hline & & $(3,6009)$ \\
\hline \multirow[t]{2}{*}{ Constant } & $4,2 \mathrm{e}+03^{\star * *}$ & $4,3 e+03^{* * *}$ \\
\hline & $(3,9265)$ & $(6,0783)$ \\
\hline Observations & 50 & \\
\hline$\lambda$ & 1,5542 & \\
\hline Competition ( $p$-value) & 0,0029 & \\
\hline Cartel & 0,2890 & \\
\hline \multicolumn{3}{|l|}{ (p-value) } \\
\hline Cournot & 0,0437 & \\
\hline (p-value) & & \\
\hline
\end{tabular}

On the other hand, we do not reject the hypothesis of cartel behavior. The overcharge is obtained by substituting an alternative value for $\lambda^{A}$ that is compatible with Cournot oligopoly: the Herfindahl-Hirschman index of concentration. With this procedure, we find overcharge of about 9.3\%. Applying the monthly overcharge to the observed quantities between 1998 and 2004, we find a figure of $\mathrm{R} \$ 27.88$ million for the estimated overprice (eq. 01).

\section{Fines and Estimated Overcharges}

After estimating cartel overcharges (eq. 01), we compare the results obtained with the fine effectively imposed to PBR. An important question is how to arrive at a specific value for cartel overcharges when faced with several estimates computed using different methods that cannot be $a$ prio$r i$ ranked in terms of adequacy. This issue frequently arises in court cases, when experts from both sides present estimates from different methods 
grounded on specific assumptions on modelling strategies (e.g. structural or reduced form) or model specifications (OXERA 2009). The economics literature identifies two solutions to this question. The first one would be selecting the "best" model - i.e. the best combination of modelling approach and data - and the second one would be combining all estimates into a single value.

Selecting the "best" model (e.g. structural vs. reduced form) seems like a good principle but has the drawback of having to find a good criterion for ranking such disparate modelling strategies. Both rely on more or less restrictive assumptions which cannot be conclusively accepted or rejected $a$ priori in general or for this case in particular. To our knowledge, the literature on empirical industrial organization has not arrived to a conclusion on this issue in recent debates (Angrist \& Pischke, 2010; Nevo \& Whinston, 2010). On the other hand, the "pooling of estimates" approach is common in the empirical economics literature, especially with respect to forecasting models (Hendry \& Clements, 2004). These authors point out that: (i) combining individual forecasts of the same event often outperform the individual forecasts and (ii) simple rules for combining forecasts, such as averages, often outperform more complex rules.

More specifically with respect to estimating cartel losses, (OXERA 2009) also notices both approaches, choosing a "best" model or using some sort of "pooling" approach. When there's some reason that a specific methodology is superior to all others, the authors support the usage of a single set of values.

The advantages of a "pooling" approach set forth in (OXERA 2009) are more in line with the present study, as the following quotes indicate:

"When the models rely on different sub-sets of available data, combining the forecasts means that the final value reflects more of the underlying data (and hence more of the available information) than a single model alone.[...] Even when care is taken during the model estimation, there may be biases in the individual models due to the particular assumptions and model structure employed. Pooling the results is likely to help reduce these, as positive and negative biases tend to cancel one another out, at least to some extent" (OXERA 2009) 
The authors also caution against a simple average of all models, suggesting instead that removing approaches and estimates with weaknesses - a practice they call as "trimming". Considering these points, we used averages of our estimates as our baseline estimate for overcharges. In the following Table 5, we present the estimated overcharges and the additional revenue due from cartel action, considering the quantity actually sold throughout the period between 1998 and 2004.

We need two additional adjustments to make the comparison between the overcharge multiplied by sales and the fines levied by firms. The first one involves the different time periods used in our calculations and the one used by CADE. While we use the period between 1998 and 2004, the competition authority considered the period between 1995 and 2004. So, we made a proportional adjustment of the estimated values since we do not have information on quantities sold before 1998. The second adjustment concerns adjusting the values for the period between the leniency agreement to the conviction date. We used the same factor (based on SELIC money market rate) applied by the authorities as described in the case file ${ }^{31}$ to express money figures in BRL at the time of final ruling, May $9^{\text {th }}, 2012$. These adjustments give the "Adjusted Estimate" figures in Table 5.

Finally, we also make one adjustment to the fines applied by CADE. Since Degussa was exempted from fines because of the leniency agreement with CADE, we estimated what would have been the total fines applied if Degussa had not been exempted by dividing the fine applied to PBR by its market share as defined by the cartel: 60\%. This gives the "Adjusted Fine" figure on Table 5 and figure 6 . Table 5 brings together the adjusted cartel overprices (panel A) and the estimated total values and fine applied (panel B). Figure 6 gives a visual comparison of the figures obtained.

31 The factor, 2.026987, was computed from the SELIC rate available at the Receita Federal do Brasil (Brazil's tax authority) website and is the rate required by law 9021/1995 for adjusting values of the fines. We chose to report all values for the same date as of the final ruling (May $9^{\text {th }} 2012$ ) to highlight the differences in values exclusively from different methodologies and assumptions and not hypotheses on adjusting values for inflation. 
Table 5 - Overcharge, Total Fine, and Overcharge multiplied by sales

\begin{tabular}{|c|c|c|c|c|}
\hline Method & Notes & $\begin{array}{l}\text { Overcharge } \\
\text { (R\$/ton) }\end{array}$ & $\begin{array}{l}\text { Overprice X Sales } \\
\text { (million) }\end{array}$ & $\begin{array}{l}\text { Adjusted Overprice X Sales } \\
\text { (million) }\end{array}$ \\
\hline Structural & & 68.67 & 27.88 & 94.19 \\
\hline TS1 & $\begin{array}{l}\text { First Degree Polynomial } \\
\text { Trend + Cartel Ending Jan } \\
2004\end{array}$ & 136.32 & 55.35 & 186.98 \\
\hline TS2 & $\begin{array}{l}\text { First Degree Polynomial } \\
\text { Trend + Cartel Ending Feb } \\
2004\end{array}$ & 88.89 & 36.09 & 121.92 \\
\hline TS3 & $\begin{array}{l}\text { Second Degree Polynomi- } \\
\text { al Trend + Cartel Ending } \\
\text { Jan } 2004\end{array}$ & 162.23 & 65.87 & 222.52 \\
\hline TS4 & $\begin{array}{l}\text { Second Degree Polynomi- } \\
\text { al Trend + Cartel Ending } \\
\text { Feb } 2004\end{array}$ & 114.53 & 46.50 & 157.09 \\
\hline TS5 & $\begin{array}{l}\text { Third Degree Polynomial } \\
\text { Trend + Cartel Ending Jan } \\
2004\end{array}$ & 156.21 & 63.42 & 214.26 \\
\hline TS6 & $\begin{array}{l}\text { Third Degree Polynomial } \\
\text { Trend + Cartel Ending Feb } \\
2004\end{array}$ & 105.80 & 42.96 & 145.12 \\
\hline DD1 (BR vs. SA) & Linear Trend & 75.18 & 30.52 & 103.12 \\
\hline DD2 (BR vs. SA) & $\begin{array}{l}\text { Linear Trend+Mkt. Spec } \\
\text { Linear Trends }\end{array}$ & 148.33 & 60.22 & 203.45 \\
\hline DD3 (BR vs. SA) & $\begin{array}{l}\text { Linear Trend+Mkt. Spec } \\
\text { Quad. Trends }\end{array}$ & 280.02 & 113.69 & 384.08 \\
\hline DD4 (BR vs. SA) & $\begin{array}{l}\text { Linear Trend+Mkt. Spec } \\
\text { Cubic Trends }\end{array}$ & 207.06 & 84.07 & 284.01 \\
\hline DD5 (BR vs. USA) & Linear Trend & 59.86 & 24.30 & 82.10 \\
\hline DD6 (BR vs. USA) & $\begin{array}{l}\text { Linear Trend+Mkt. Spec } \\
\text { Linear Trends }\end{array}$ & 140.11 & 56.89 & 192.18 \\
\hline DD7 (BR vs. USA) & $\begin{array}{l}\text { Linear Trend+Mkt. Spec } \\
\text { Quad. Trends }\end{array}$ & 242.08 & 98.29 & 332.05 \\
\hline DD8 (BR vs. USA) & $\begin{array}{l}\text { Linear Trend+Mkt. Spec } \\
\text { Cubic Trends }\end{array}$ & 195.92 & 79.55 & 268.73 \\
\hline DD9(All) & Linear Trend & 67.52 & 27.41 & 92.61 \\
\hline DD10 (All) & $\begin{array}{l}\text { Linear Trend+Mkt. Spec } \\
\text { Linear Trends }\end{array}$ & 144.22 & 58.55 & 197.81 \\
\hline DD11 (All) & $\begin{array}{l}\text { Linear Trend+Mkt. Spec } \\
\text { Quad. Trends }\end{array}$ & 261.05 & 105.99 & 358.07 \\
\hline DD12 (All) & $\begin{array}{l}\text { Linear Trend+Mkt. Spec } \\
\text { Cubic Trends }\end{array}$ & 201.49 & 81.81 & 276.37 \\
\hline Average & & 150.29 & 61.02 & 206.14 \\
\hline Fine & & & & 97.13 \\
\hline Adjusted fine & & & & 161.88 \\
\hline
\end{tabular}




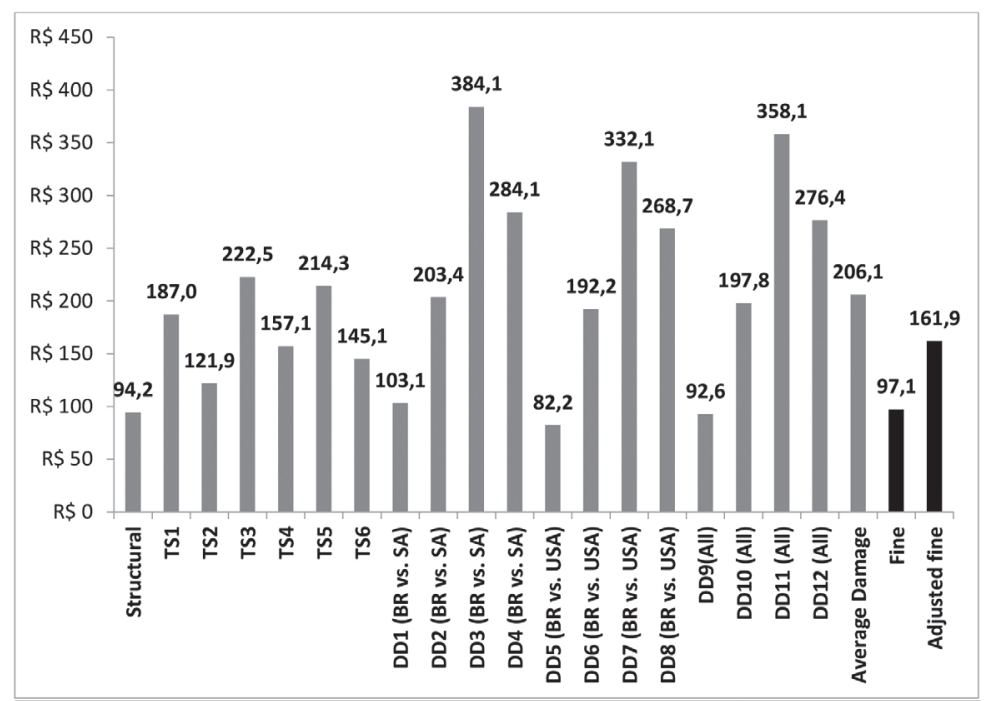

Figure 6 - Fine and Overcharges ( $\mathrm{R} \$$ millions)

Source: case file and own calculations.

It is clear from Table 5 and Figure 6 that there is a large discrepancy between the values estimated by different methods, which indicates the important role played by different assumptions on the resulting estimates. The range of estimates starts at a minimum of $\mathrm{R} \$ 82.1$ million to a maximum of R $\$ 384.08$ million: a 368\% difference. A striking example of this point is shown by the reduced form estimates found using the time series and the difference in difference methods. Table 6 presents estimates of the mean overcharge for the before and after and for the differences in difference estimates (pooling all estimates and trimming the non-linear trends). One can notice the standard deviation reduces by almost half.

Table 6 - Descriptive Statistics of Overprice estimates

\begin{tabular}{llllll}
\hline Method & Mean & Maximum & Minimum & SD & Range \\
\hline Time Series & $\mathrm{R} \$ 174.65$ & $\mathrm{R} \$ 222.52$ & $\mathrm{R} \$ 121.92$ & $\mathrm{R} \$ 39.93$ & $\mathrm{R} \$ 100.60$ \\
Diff-in-Diff & $\mathrm{R} \$ 231.21$ & $\mathrm{R} \$ 384.08$ & $\mathrm{R} \$ 82.10$ & $\mathrm{R} \$ 103.19$ & $\mathrm{R} \$ 301.99$ \\
Diff-in-Diff (2) & $\mathrm{R} \$ 145.21$ & $\mathrm{R} \$ 203.45$ & $\mathrm{R} \$ 82.10$ & $\mathrm{R} \$ 58.12$ & $\mathrm{R} \$ 121.35$ \\
\hline
\end{tabular}

Diff-in-Diff (2): Descriptive Statistics from estimates with linear trend and linear market specific trends, trimming DD3, DD4, DD7 and DD8. 
Such a large dispersion in cartel overcharge and damage estimates indicates caution in applying any single set of estimates as a basis for computing cartel fines. The results point out that, as a practical matter, it would be advisable to have several estimates arrived at by different methods to act as guideline for setting fines. These estimates could also be used as a starting point for litigants aiming at starting cases in Brazilian Civil Courts for redress of losses caused by this price fixing conspiracy.

As for the second research question, the adjusted fine of $\mathrm{R} \$ 161.9$ million is approximately in the middle of the range of estimates for the Time Series (Before and After) and somewhat above the middle of the range of estimates for the Diff-in-Diff approach, trimming the polynomial market specific trends. This indicates one cannot say the level of fines is out of line with cartel overcharges, even though cartel overcharges are only a part of total cartel damages. Deadweight losses and losses from passing the price increase to consumers downstream are not considered in these estimates. At least in this specific case, the setting of fines based on sales revenue does not seem to lead to excessively low fines. The most one can say on this matter, considering the estimates presented, is that the level of fines might not be enough to implement the optimal deterrence strategy (Landes 1983).

\section{Conclusion}

This paper has two goals. The first one is to use real case data from a cartel conviction case, the hydrogen peroxide cartel, to highlight the pitfalls associated in estimating cartel overcharges under time and data resource constraints similar to those faced by completion officials in real cases. The second one is to compare the fines levied on the convicted firm with the cartel overcharges during the cartel period, since the existing law only provides guidance for computing cartel fines based on sales revenue, and not on the actual cartel overcharges.

We applied three different methods to data produced during the investigation phase: a reduced form, before and after and difference in difference, model and a structural model of supply and demand for imperfectly competitive markets. The results of all models show large dispersion, 
reflecting the effects that different modelling assumptions and strategies have on these estimates. Such a large dispersion in estimates indicates the need of caution in applying any single one of them as a basis for computing cartel fines. The results point out that, as a practical matter, it would be advisable to have several estimates arrived at by different methods to act as guideline for setting fines. These estimates could also be used as a starting point for litigants aiming at starting cases in Brazilian Civil Courts for redress of losses caused by this price fixing conspiracy.

As for the second research question, the adjusted fine of $\mathrm{R} \$ 161.9$ million is approximately in the middle of the range of estimates for the Time Series (Before and After) and somewhat above the middle of the range of estimates for the difference in differences approach, trimming the polynomial market specific trends. This indicates one cannot say the level of fines is out of line with cartel overcharges, even though cartel overcharges are only a part of total cartel damages. This does not imply the cartel fine is optimal in any sense defined by the literature, because deterrence aspects should also be factored in the final number.

As a policy recommendation in such a controversial issue, our results point to a pluralistic approach. When calculating estimates of cartel overcharges, the safest course seems to employ several techniques, ideally starting from different assumptions. A set of estimates could reduce the effect of assumptions made in the implementation of one individual methodology. Besides, the results should be compared with fines computed as a percentage of sales. Since Law 12.529 and its predecessor (Law 8.884) both allowed some leeway in determining the inputs for which sales figures were to be computed, having an alternative estimate of cartel overcharges could help with that also. 


\section{References}

Angrist, J., \& Pischke, J.-S. (2009). Mostly Harmless Econometrics. Princeton, NJ: Princeton University Press. Angrist, J., \& Pischke, J.-S. (2010). The Credibility Revolution in Empirical Economics: How Better Research Design Is Taking the Con out of Econometrics. Journal of Economic Perspectives, 24(2), pp. 3-30.

Baker, J., \& Rubinfeld, D. (1999). Empirical Methods in Antitrust Litigation: Review and Critique. American Law and Economics Review, 386-435.

Black, H. (1991). Black's Law Dictionary with Pronunciations (6th ed.). West Group.

Connor, J., \& Lande, R. (2008). Cartel Overcharges and Optimal Cartel Fines. In S. Waller, Issues in Competition Law and Policy (Vol. 3, pp. 2203-2218). ABA Section of Antitrust Law.

Connor, J., \& Lande, R. (2008). Issues in Competition Law and Policy. In Issues in Competition Law and Policy (Vol. 3, p. 2203\{2218). Law, ABA Section of Antitrust.

Crooke, P., Froeb, L., Tschantz, S., \& Werden, G. (1999). Effects of assumed demand form on simulated postmerger equilibria. Review of Industrial Organization, pp. 205-217.

Doraszelski, U., \& Pakes, A. (2007). A Framework for Applied Dynamic Analysis in IO. In M. Armstrong, \& R. Porter, Handbook of Industrial Organization (Vol. 3, pp. 1887-1966). Elsevier.

Genesove, D., \& Mullin, W. (1998). Testing static oligopoly models: conduct and cost in the sugar industry, 1890-1914. RAND Journal of Economics, pp. 355-377.

Harrington, Jr., J. (2004, December). Post-Cartel Pricing during Litigation. The Journal of Industrial Economics, $52(4), 517-533$.

Hendry, D. F., \& Clements, M. P. (2004). Pooling of Forecasts. Econometrics Journal, pp. 1-32.

Landes, W. (1983). Optimal sanctions for antitrust violations. The University of Chicago Law Review, 50(2), $652-678$.

Levenstein, M., \& Suslow, V. (2004). Studies of Cartel Stability: A Comparison of Methodological Approaches. In P. Grossman, How Cartels Endure and How they Fail: Studies of Industrial Collusion. Edward Elgar.

Nevo, A., \& Whinston, M. (2010). Taking the Dogma out of Econometrics: Structural Modeling and Credible Inference. Journal of Economic Perspectives, 24(2), pp. 69-82.

OECD. (2002). Report on the Nature and Impact of Hard Core Cartels and Sanctions against Cartels under National Competition Laws.

OXERA. (2009). Quatifying Antitrust Damages: towards non-binding guidance for courts. Luxembourg: Publications Officeof the European Union. Retrieved from http://ec.europa.eu/competition/antitrust/ actionsdamages/

Posner, R. (2001). Antitrust Law (2nd ed.). Chicago, IL: The University of Chicago Press.

Werden, G. (2003, Janeiro). The Effect of Antitrust Policy on Consumer Welfare: What Crandall and Winston Overlook. Economic Analysis Group discussion paper. 